\title{
PREPARAÇAO PARA A VIDA, PREPARAÇAO PARA A MORTE: PEDAGOGIA E CATEQUESE NO DE CATECHIZANDIS RUDIBUS DE SANTO AGOSTINHO
}

\author{
PREPARATION FOR LIFE, PREPARATION FOR DEATH: \\ PEDAGOGY AND CATECHESIS IN THE DE CATECHIZANDIS \\ RUDIBUS OF SAINT AUGUSTINE
}

Antonio Patativa de Sales*

Recebido: 05/2018

Aprovado: 06/2018

\begin{abstract}
Resumo: O De catechizandis rudibus, de Santo Agostinho (354-430), foi redigido por volta de 405. Trata-se de uma resposta ao apelo do diácono Deogratias, que lhe pedira instruções sobre o melhor modo de ensinar os rudimentos da fé cristã aos candidatos ao catecumenato, na paróquia de Cartago. Mesmo que a obra tenha esse viés teológico, é fácil notar, pela genialidade do Hiponense, alguns aspectos teórico-prático-pedagógicos que interessam ao estudo da pedagogia antiga, e à catequese de modo geral. O De catechizandis rudibus sintetiza aquilo que a Igreja cristã, até a época, melhor havia produzido em matéria de transmissão de conhecimentos - afincada à doctrina christiana e à moral teológica. Por tais aspectos é que falamos de uma "Preparação para a vida, preparação para a morte". Para além da horizontalidade, o De catechizandis apresenta uma verticalidade teleológico-doutrinal que visa preparar os homens na/da civitas terrena, a fim de conduzi-los à civitas celeste, a civitas Dei. "[...] o que se chama uma razão de viver", dizia Alberto Camus, "é ao mesmo tempo uma excelente razão de morrer." É por aí, pelo viés da fé cristã e da razão comum, que analisamos a pedagogia do Hiponense no De catechizandis rudibus, às vezes nos remetendo a outras obras.
\end{abstract}

Palavras-chave: Pedagogia. Filosofia. Teologia. Patrística. Educação.

\begin{abstract}
The De catechizandis rudibus, by St. Augustine (354-430), was written around 405. It is a response to the deacon Deogratias' call for instructions on how best to teach the rudiments of the Christian faith to candidates to the catechumenate, in the parish of Carthage. Even if the work has this theological bias, it is easy to note, by the genius of the Hyconian, some theoretical-practicalpedagogical aspects that are of interest to the study of ancient pedagogy, and to catechesis in general. De catechizandis rudibus sums up what the Christian Church, at that time, had better produced in terms of the transmission of knowledge - based on Christian doctrine and theological morality. By such aspects is that we speak of a "Preparation for life, preparation for death". In addition to horizontality, the De catechizandis presents a teleological-doctrinal verticality that aims to prepare men in the civitas terrena, in order to lead them to civitas celeste, the civitas Dei. "What is called a reason to live," said Alberto Camus, "is at the same time an excellent reason for dying." It is there, through the bias of the Christian faith and common reason, that we analyze pedagogy of the Hipponense in the De catechizandis rudibus, sometimes referring to other works.
\end{abstract}

Keywords: Pedagogy. Philosophy. Theology. Patristic. Education.

\footnotetext{
* Antonio Patativa de Sales é prof. Dr. em Teologia (EST-IEPG), na área de Teologia e História; e Dr. em Filosofia (UFPB), na área de Metafísica.
} 


\title{
Introdução
}

"V. Caridade preste atenção. É questão importante, grande questão."1

"Na medida do possível, viro-me do avesso para vocês."

Em O mito de Sísifo (1942), de Albert Camus (1913-1960), há esta citação:

\begin{abstract}
Nunca vi ninguém morrer pelo argumento ontológico. Galileu, que possuía uma verdade científica importante, dela abjurou com a maior das facilidades deste mundo, logo que tal verdade pôs a sua vida em perigo. Fez bem, em certo sentido. Essa verdade não valia a fogueira. Qual deles, a Terra ou o Sol, gira em redor do outro, é-nos profundamente indiferente. A bem dizer, é um assunto fútil. Em contrapartida, vejo que muitas pessoas morrem por considerarem que a vida não merece ser vivida. Outros vejo que se fazem paradoxalmente matar pelas ideias ou pelas ilusões que lhes dão uma razão de viver (o que se chama uma razão de viver é ao mesmo tempo uma excelente razão de morrer). Julgo, pois, que o sentido da vida é o mais premente dos assuntos - das interrogações. ${ }^{1}$
\end{abstract}

O argumento sucede a questão inicial (e principal) colocada à filosofia, a questão do suicídio - e do suicídio filosófico, conforme o autor, requerido pela religião. Em Santo Agostinho (354-430), e apesar de todos os séculos que o distanciam do escritor francês, questões de vida ou morte transitam em uma frágil ponte estendida entre o tempo e a eternidade - esta que, como já tratado em outro artigo nosso ${ }^{2}$, é um axioma necessário à resposta da fé, e que a teologia pretende enquanto tal. Essa urgência e necessidade - aquilo que Paul Tillich (1886-1965) chamaria de "preocupação última"3, faz do Hiponense, ainda hoje, um pensador muito atual. "Santo Agostinho", como Karl Jaspers (1883-1969) afirma, "pensa perguntando" . Da sua doutrina da interioridade e análises psicológicas - ele é o

\footnotetext{
${ }^{1}$ Enn. in Ps., 35, 10.

${ }^{2}$ Enn. in Ps., 32, S. I,5.

${ }^{1}$ CAMUS, Albert Camus. O mito de Sísifo. Lisboa: Livros do Brasil, 2005. p. 13-14. O contexto da citação: "Só há um problema filosófico verdadeiramente sério: é o suicídio." De fato, coisas como "julgar se a vida merece ou não ser vivida, é responder a uma questão fundamental da filosofia", e "o resto, se o mundo tem três dimensões, se o espírito tem nove ou doze categorias, vem depois." (CAMUS, 2005. p. 13-14).

${ }_{2}$ Trata-se do artigo "Sabedoria e felicidade: a eternidade como axioma fundamental, em Santo Agostinho", apresentado como comunicação no XI Congresso Latino-Americano de Filosofia Medieval, promovido pela Comissão Brasileira de Filosofia Medieval, em 25 de agosto de 2006, na UFCE, em Fortaleza, CE.

${ }^{3} \mathrm{Ou}$ seja: "O objeto da teologia é aquilo que nos preocupa de forma última. Só são teológicas aquelas proposições que tratam de seu objeto na medida em que ele pode se tornar questão de preocupação última para nós." (TILLICH, Paul. Introdução. In: Teologia sistemática. 3. ed. São Leopoldo: Sinodal / IEPG, 2000. p. 20).

${ }^{4}$ JASPERS, Karl. Apud WILLS, Garry. Santo Agostinho. Rio de Janeiro: Objetiva, 1999. p. 9.
} 
primeiro a compor uma autobiografia, mesclando a história da sua vida com o progresso do seu pensamento - somos herdeiros, conscientes ou não. Outras questões que o Hiponense coloca, e que dominaram a Idade Média, ainda são, na atualidade, renovadas e aprofundadas. Três exemplos: Martin Heidegger (1889-1976) valeu-se da linguagem como problema hermenêutico aplicado ao signo e ao significado (vinculado à linguagem e à ontologia enquanto hermenêutica da facticidade), modelo hermenêutico do qual Agostinho seria pioneiro 5 ; Ludwig Wittgenstein (1889-1951), dentre outros que veem no De magistro (389) o germe da moderna Filosofia da Linguagem ${ }^{6}$, utilizando uma passagem das Confissões, de modo crítico, aproxima-o de outras questões recorrentes na contemporaneidade ${ }^{7}$; Hans-Georg Gadamer (1900-2002), finalmente, notou a pretensão de universalidade da hermenêutica agostiniana, e aprofundou-lhe alguns conceitos, estudados agora mesmo em academias seculares e escolas teológicas de todo o mundo. ${ }^{8}$

\footnotetext{
${ }^{5}$ A hermenêutica agostiniana, por sua natureza conciliar e inovadora, mas principalmente pela sua pioneira utilização da linguagem como problema hermenêutico aplicado - como a distinção entre actus signatus (elocução predicativa) e actus exercitus (sua concretização), por exemplo -, foi tão eficaz que, mesmo na Modernidade, encontrou admiradores como Heidegger e Gadamer. (Cf. GRONDIN, Jean. Introduction to Philosophical Hermeneutics. New Haven; London: Yale University Press, 1994, p. 32-33). De fato, no verão de 1923, Heidegger deu início a algumas lições sobre a hermenêutica da facticidade e, aí, ele considera o Livro III do De doctrina christiana como modelo e marco da hermenêutica de grande estilo, que sobrepuja a posterior, mais formal - como afirmou Friedrich D. E. Schleiermacher (1768-1834), dizendo que aquela "limitou, então, a idéia da hermenêutica, encarada de forma abrangente e viva (cf. Agostinho!) a uma 'arte (doctrina artis) da compreensão'." (GONDRIN, 1994, p. 33).

${ }^{6}$ As obras que tratam sobre a filosofia da linguagem, em Agostinho, são numerosas. Dentre as tais: VECCHIO, S. Le parole come segni. Introduzione alla linguistica agostiniana. Palermo: Novecento, 1994; RINCÓN GONZALEZ, A. Signo y Lenguaje en San Agustín. Bogotá: Universidad Nacionalde Colombia,1992; CRICCO, V. Semiótica agustiniana: el diálogo El maestro de San Agustín. Morón: Universidad de Morón, 2000; ALICI, L. Il linguaggio come segno e come testimonianza. Una riletura di S. Agostino. Roma: Studium, 1976; ANGELES NAVARRO GIRON, M. Filosofia del lenguaje en San Agustín. Madrid: Editorial Revista Agustiniana, 2000; BURNYEAT, M. F. Wittgenstein and Augustine De magistro. In: MATTHEWS, Gareth B. (Ed.). The augustinian tradition. Berkeley, Los Angeles, London: University of California Press, 1999. p. 286303.

7 "Entre os polos temáticos em torno dos quais se concentram os estudos sobre o influxo de Agostinho na filosofia contemporânea destaca-se sem dúvida a questão da linguagem, enquanto horizonte de fundo dentro do qual se encontra uma ampla gama de questões, da gênese do sentido à função do signo e à dinâmica da comunicação. Quem chamou a atenção para a reflexão agostiniana sobre o signo no século XX foi efetivamente L. Wittgenstein, especialmente em texto como Brown Book, Philosophische Untersuchungen e Philosophische Grammatik. E não é por acaso que seja justamente Wittgenstein o representante quase emblemático da ambivalência de um confronto com Agostinho, continuamente oscilante entre admiração e dissenso. É assaz conhecido o fato de que ele inicia as Investigações filosóficas citando uma passagem das Confissões de Agostinho, isto é, uma parte do parágrafo 8 do Livro I.” (SANTOS, Bento Silva. Introdução. In: AGOSTINHO, Santo. De magistro. Petrópolis: Vozes, 2009. p. 49. [Col. Textos Fundamentais de Educação]).

8 "Segundo o testemunho de Gadamer, Heidegger encontrou em Agostinho uma fonte, embora não a mais importante, para a sua concepção do 'sentido ratificador' (Vollzugsinn) da elocução, uma concepção que ele contrapunha à tradição metafísico-idealista. [...] Uma profunda recepção de Agostinho também pode comprovarse em Gadamer. [...] foi mencionado um colóquio, no qual Gadamer relacionou retroativamente com Agostinho a pretensão de universalidade hermenêutica. A ele foi igualmente dedicado um capítulo decisivo de 'Verdade e Método'. Decisivo não é dizer demasiado, porque ali Gadamer permitiu a Agostinho ir além do esquecimento da
} 
A questão pedagógica, como veremos, não fica atrás de nenhuma outra; mesmo que, e ao menos em nosso país, ainda seja abordada de modo mais ou menos tímido.

\section{Agostinho, mestre do Ocidente}

Por influência de sua vastíssima produção literária, vida e genialidade, Agostinho foi reconhecido como "mestre do Ocidente". Suas obras, dos primeiros diálogos em Cassissiacum (386) ao polêmico Contra segundam Juliani responsionem opus imperfectum (429-30), foram armas não somente contra as heresias que proliferavam entre os cristãos do primeiro século, mas pelos séculos seguintes, e a base da cultura moral e espiritual do Ocidente Medieval, e ainda depois. "Agostinho é a Patrística", diz Johannes Hirshberger (1900-1990) ${ }^{9}$, enfatizando seu lugar de destaque entre tantos Padres e filósofos do período (sécs. I ao VIII).

Tratar sobre o alcance e influência de suas obras, entre aqueles que o comentam, é lugar comum; e mesmo agnósticos ou ateus confessos, como Bertrand Russell (1872-1970), não lhe negam respeito e admiração ${ }^{10}$. Já antes do século IX - que é quando, segundo J. N. Hillgarth, a influência do Hiponense seria "sentida mais claramente"11 -, e até a segunda

linguagem da ontologia grega, a qual se caracterizava por uma compreensão técnico-nominalista da linguagem. Gadamer pôde mostrar em Agostinho - e sua imensa relevância emerge disso - que este esquecimento da linguagem não foi total na tradição. O pensamento agostiniano do verbum já teria feito jus, na tradição, ao ser da linguagem." (GONDRIN, 1994, p. 33).

${ }^{9}$ HIRSHBERGER, Johannes. História da filosofia na Idade Média. 2. ed. São Paulo: Editora Herder, 1966. p. 29. Logo na sequência, utilizando-se de duas citações de conhecidos comentadores de Agostinho, Hirschberger acrescenta: "“A influência patrística na Filosofia medieval coexiste com a sobrevivência e o continuado influxo de AGOSTINHO na Idade Média' [...]. Que pode chamar-se o mestre do Ocidente, mostra-o o fato da sua influência ainda para além da Idade Média. É uma das colunas da Filosofia cristã de todos os tempos. 'Com AGOSTINHO chegamos ao ponto culminante da Patrística e, talvez, do toda a Filosofia cristã' [...]”. (HIRSHBERGER, 1966, p. 29).

${ }^{10}$ Russel diz que, em Agostinho, por exemplo, há "uma exposição melhor e mais clara do que a de Kant acêrca da teoria subjetiva do tempo - uma teoria que, desde Kant, tem sido amplamente aceita entre os filósofos. A teoria de que o tempo é apenas um aspecto de nossos pensamentos é uma das formas mais extremadas do subjetivismo que [...] aumentou pouco a pouco na antiguidade, a partir de Protágoras e Sócrates. Seu aspecto emocional é a obsessão do pecado, que veio mais tarde que os seus aspectos intelectuais. Santo Agostinho revela ambas as espécies de subjetivismo. O subjetivismo leva-o a antecipar não só a teoria do temo, de Kant, como o cogito de Descartes. Em seus Solilóquios, diz: 'Tu, que queres saber, sabes quem és? Sei. Onde estás? Não sei. Sabes que tu pensas? Sei.' Isto contém não apenas o cogito de Descartes, mas sua resposta ao ambulo ergo sum de Gassendi. Como filósofo, portanto, Agostinho merece um alto lugar." (RUSSEL, Bertrand. História da Filosofia Ocidental. In:

Obras filosóficas. 3. ed. São Paulo: Companhia Editora Nacional / CODIL, 1969. p. 56-57. [Col. Biblioteca do Espírito Moderno: Filosofia]. v. 2).

11 HILlgaRTH, J. N. Cristianismo e paganismo, 350-750: a conversão da Europa ocidental. São Paulo: Madras, 2004. p. 21: "A especulação de Agostinho ou Boetio era inacessível e seria incompreensível mesmo para o mais estudado homem da época", diz Hillgarth, acrescentando que "a influência dessas obras foi sentida muito mais claramente a partir do século IX". Antes, dissera: "A cultura romana mais posterior era 
metade do século XII, principalmente na França, ele domina os campos teológico-filosófico: na reprodução de suas ideias, nas tentativas de superá-las, adaptá-las, etc. Para Sto. Tomás (1225-74), Agostinho "é tido como intocável”, e o Aquinate “evita ao máximo contradizer as afirmações do Mestre do Ocidente. ${ }^{12}$ "Através do Doutor Angélico, e até a Reforma protestante (séc. XVI), o Hiponense continua falando, sendo invocado como autoridade, como mestre. ${ }^{13}$

Na França do século XVII, o aclamado "século de Agostinho"14, muita coisa mudara com a (re)ascensão do tomismo; mas o Bispo de Hipona ainda era fartamente citado, estudado e reverenciado - como na Conversa com o Sr. de Sacy sobre Epiteto e Montaigne, atribuída a Blaise Pascal (1623-1662). O Sr. de Sacy, depois de cumprimentar Pascal por interpretar tão bem Montaigne e Epiteto, "poderia lhe dizer sem cerimônia que dominava bem melhor Santo Agostinho e que sabia interpretá-lo bem melhor, ainda que com pouca vantagem em favor do pobre Montaigne. ${ }^{15 "}$ Na primeira parte d'o Ingênuo, conto de Voltaire (1694-1778) publicado

predominantemente literária e demonstrada principalmente por citações apropriadas, cumprimento educado ou epigrama. Ainda assim, quem podia acompanhar a elaborada sátira das cartas de São Jerônimo ou mesmo a dialética da Cidade de Deus, de Santo Agostinho, era pouco em número. Não é por acaso que uma grande parte deste livro consiste de sermões e vidas de santos". (HILLGARTH, 2004, p. 20-21). Os santos são modelos simples de conduta e moral cristãs a serem imitados; e escrever sobre eles dispensavam as elaboradas especulações filosófico-teológicas. As hagiografias tornaram-se famosas.

${ }^{12}$ LUPI, João. Tomás lê Orígenes. In: DE BONI, Luis A.; PICH, Roberto H. A recepção do pensamento grecoromano, árabe e judaico pelo Ocidente Medieval. Porto Alegre: EDIPUCRS, 2004. p. 488. (Col. Filosofia, 171). Sobre o respeito de Tomás de Aquino por Agostinho, em comparação a Orígenes, Lupi questiona: "Se é a influência do platonismo que desagrada a Tomás, é como o arsenal de Aristóteles que ela é combatida, o que também é explícito e freqüente. Não é só o aristotelismo que faz a Escolástica, é a rejeição da tradição platônica dentro da Patrística e do Cristianismo. Resta a pergunta: e Agostinho, que tanto venera Platão, porque nunca é criticado? Porque é que em Orígenes se vêem as más influências platônicas, e em Agostinho não? São as escolhas de Tomás, de demorariam muito tempo para explicar, mas cuja existência é inegável." (LUPI, 2004, p. 496-97). "Não será exagero dizer-se que a alta estatura de Agostinho domina toda a Filosofia Medieval. O que não significa que sua autoridade (principalmente a partir do século XIII) seja admitida, sempre e por toda a parte, sem contestação." (JEAUNEAU, Édouard. A Filosofia Medieval. Lisboa: Edições 70, 1980. p. 13. [Col. Biblioteca Básica de Filosofia]).

${ }^{13}$ De tantos testemunhos sobre a grandeza e a influência de Agostinho, o de W. Walker é modelar: "Em Agostinho a Igreja antiga atingiu o seu ponto religioso mais elevado desde os tempos apostólicos. Sua influência no Oriente foi relativamente pequena, em virtude da natureza dos problemas de que principalmente se ocupou. Todo o cristianismo ocidental, porém, é-lhe devedor. A ele, mais que a qualquer outro personagem, deveu-se a superioridade que a vida religiosa no Ocidente veio a ter sobre a do Oriente. Estava fadado a ser pai de muitos dos que viriam a ser os elementos mais característicos do catolicismo romano medieval, como, de resto, igualmente da Reforma [séc. XVI]. Fundamentada embora nas Escrituras, na filosofia e na tradição eclesiástica, sua teologia enraizava-se tão profundamente na sua própria experiência que a sua história pessoal adquire foros de verdadeira interpretação do homem." (WALKER, Williston. História da Igreja cristã. 4. ed. Rio de Janeiro: JUERP; São Paulo: ASTE, 1983. p. 231. v. 1).

14 “[Os] séculos XVI e XVII podem ser vistos como um imenso florescimento da espiritualidade agostiniana ao longo de todas as diferenças de crenças, que continuou em seu próprio caminho pelo iluminismo." (TAYLOR, Charles. As fontes do self: a construção da identidade moderna. São Paulo: Loyola, 1997. p. 186).

${ }^{15}$ PASCAL, Blaise. Conversa com o Senhor de Sacy sobre Epiteto e Montaigne e outros escritos. São Paulo: Alameda, 2014. p. 73-74. O autor da Conversa, sabe-se agora, é N. Fontaine (1625-1709), então secretário de Louis-Isaac Le Maistre de Sacy, o Sr. de Sacy (1613-1684). "A origem da Conversa de Pascal com o Senhor de 
em 1767 e ambientado no ano de 1689, o Abade de Kerkabon, prior de Nossa Senhora da Montanha, é "elogiado" por ser "o único clérigo da província que não precisava ser carregado para o leito depois de cear com os seus confrades". Também o Abade de Kerkabon "sabia muito corretamente a sua teologia e, quando cansado de ler Santo Agostinho, divertia-se com Rabelais: de modo que todos diziam bem dele. ${ }^{16 "}$ Referência que, mesmo quando se considera os limites deste tipo de literatura, diz muito sobre o domínio da teologia do Hiponense por aqueles tempos. Ele, por muitos motivos, mantinha-se atual; um que tinha muito a ser dito: por sua teologia e por sua escrita pulsante, como na aclamada Confissões. Nela, e não somente nela, as temáticas que ele suscita mantêm-no atualíssimo. Nas palavras de HenriIrénée Marrou (1904-1977), um seu comentador:

Nada atesta melhor a posição de primeira plana ocupada por Santo Agostinho na mentalidade do século XVII em França que o papel desempenhado por ele na evolução do cartesianismo. Mersenne, já na primeira leitura do Discurso do Método, e o grande Arnauld, logo depois da publicação das Meditações metafísicas, assinalaram a Descartes a coincidência surpreendente entre certos raciocínios do grande Doutor e o argumento do cogito. Entretanto, é o caso de perguntar se Descartes conheceu efetivamente ou não tais textos? ${ }^{17}$

Também em Portugal, a grande influência de Agostinho será uma rica herança às futuras colônias. Em 1989, no estudo que examina as influências do pensamento do Hiponense na pátria de Luís Vaz de Camões (1524-1580), feito por Francisco da Gama Caeiro (1928-1994), veem-se os grandes matizes do gênio do Hiponense, aí bem fincados ${ }^{18}$. Estudo semelhante, no Brasil, ainda não foi feito. ${ }^{19}$

Sacy remonta, portanto, ao retiro de Pascal [janeiro de 1655, em Port-Royal de Champs]. Acontece que Fontaine, seu autor, não presenciou os encontros entre os interlocutores, o que significa dizer que o opúsculo não é um relato testemunhal [mas, segundo P. Courcelle], trata-se de uma obra construída a partir de florilégios coligidos por Pascal e pelo Sr. de Sacy.” (LOQUE, Flávio Fontenelle. A conversa de Pascal com o Sr. de Lacy, ou: Sobre a utilidade da leitura de Epiteto e Montaigne. In: PASCAL, 2014, p. 15). A primeira edição da Conversa é datada em 1728, e publicada em Paris.

16 VOLTAIRE. Ingênuo: história verdadeira, tirada dos manuscritos do Padre Quesnel. In: Contos. São Paulo: Abril Cultural, 1972. p. 301. (Col. Os Imortais da Literatura Universal, 40).

${ }_{17}$ MARROU, Henri. Santo Agostinho e o agostinismo. Rio de Janeiro: Livraria Agir Editora, 1957. p. 173. (Col. Mestres Espirituais).

${ }^{18}$ Cf. CAEIRO, Francisco da Gama. Presença de Santo Agostinho no pensamento filosófico português. Didaskalia, Portugal, v. 19, n. 1, p. 81-94, 1989. Também em: Eborensia, Portugal, v. 2, n. 3-4, p. 27-38, 1989. Também a obra de DOMINGUES, Joaquim; GALA, Elísio; GOMES, Pinharanda. Santo Agostinho na cultura portuguesa: contributo bibliográfico. Lisboa: Fundação Lusíada, 2000. (Col. Lusíada - Documentos, 3). O ensaio final, Escólio bibliográfico-augustiniano (p. 83-150), de J. Pinharanda Gomes, na mesma obra, também intenciona mostrar como a presença do Hiponense é notada na base da cultura lusitana. Por fim, o livro de Praça (PRAÇA, Lopes J. J. História da filosofia em Portugal. 3. ed. Lisboa: Guimarães Editores, 1988. [Col. Filosofia e Ensaios]), principalmente das páginas 103 a 163, mostra como o vigor do pensamento agostiniano 
Na Europa do séc. XIX, enquanto o escotismo e o tomismo ganhavam mais e mais terreno, e embora as comunidades agostinianas não mostrassem o mesmo ânimo, sendo, conforme Gomes, um "complemento do tomismo escolástico", o agostinismo, "como prolegómeno de teologia e da virtude religiosa, [em] sua vertente incarnacional, [...] fundamentou o existencialismo cristão. ${ }^{20 "}$ "Ao período, dominado pela teologia do Aquinate, chamou-se Terceira Escolástica - precedida pela Escolástica Medieval e a Segunda Escolástica, que dominara o século XVII ${ }^{21}$. Mesmo aí, nas palavras de Gomes, "todos bebem de Agostinho, uns mais, outros menos, e, com efeito, não é só a Escola Franciscana que, apesar de Boaventura e de Escoto, está imersa em augustinismo." 22

sempre esteve muito vivo.

${ }^{19}$ O último capítulo de nossa tese, "A recepção da moral agostiniana no Brasil, de 1500 a 1808", dentro das devidas proporções, é uma tentativa de encontrar, em nossa formação cultural, as pegadas do Bispo de Hipona, através da literatura que foi produzida, no referido período - aqui e em Portugal. Cf. SALES, Antonio Patativa de. A filosofia/teologia moral de Santo Agostinho: dos antecedentes gregos à apropriação e interiorização do elemento cristão e sua recepção no Brasil colonial (1500-1808). São Leopoldo: EST/PPG, 2009. 296 p. (Tese de Doutorado).

${ }^{20}$ GOMES, 2000, p. 136. Em trechos das Confessiones, como: "Tudo me aborrecia, porque nada o continha e ninguém me avisava: 'Ali vem ele!', como quando voltava, ao encontrar-se ausente. Tinha-me transformado num grande problema" (Conf., IV, 4,9), na tradução clássica de J. Oliveira Santos e A. Ambrósio de Pina, os mesmos enxergam os germes de existencialismo: "Pela introspecção, Agostinho encara e defronta o ponto crucial do seu drama. Pretende o Ser, a Verdade, a Beatitude. Examina os anseios, as tendências de um abismo a pedir plenitudes. Eis, nesta frase, mais um ponto de contato do Hiponense com a filoaofia existencialista." (AGOSTINHO, Santo. Confissões. São Paulo: Nova Cultural, 1996. p. 104 [nota 01]. [Col. Os Pensadores]). Nesse sentido, e a título de introdução ao tema, ver o artigo de: GOUVÊA, Ricardo Quadros. Kierkegaard lendo Agostinho: introdução a um diálogo filosófico-teológico. In: Fides Reformata, São Paulo, v. 4, n. 2, p. 12-37, 1999. Segundo o autor, "há cerca de quarenta comentários explícitos sobre Agostinho na obra de Kierkegaard" (GOUVÊA, 1999, p. 13). Também Albert Camus (1913-1960), para o seu doutoramento em filosofia, escreveu a tese Métaphysique chrétienne et néoplatonisme, entre Plotin e Saint Augustin (1936); e embora seja conhecido pelo seu existencialismo anti-cristão, a imagem de um Agostinho que questiona o mal lhe era muito viva, como quando foi convidado para pronunciar-se aos dominicanos do mosteiro Latour-Marbourg, em Paris: "Gostaria de deixar claro o fato de que não me sinto possuidor de uma verdade absoluta ou mensagen", diz ele. "Por essa razão", continua, "jamais partirei do princípio de que a verdade cristã seja uma ilusão, porém, sempre do fato de eu não ter conseguido acesso a ela". E mais adiante: "Pergunto aos cristãos: Continuará Sócrates a ser abandonado? Arriscar-nos-emos a permanecer como assistentes à já tantas vezes repetida execução de Sócrates? Nós estamos diante do mal. Sinto-me realmente como Agostinho antes da sua conversão: 'Procurava pela origem do mal, mas não conseguia resolver essa questão'. Mas eu sei, juntamente com outros, o que fazer, pelo menos para não aumentar o mal, se podemos limitá-lo. [...] E se os cristãos não nos ajudarem nisso, quem então, nesse mundo, poderá ajudar-nos?" (CAMUS apud BERNDT, Aldo. Absurdo, revolta e exílio na obra de Albert Camus. In: Estudos teológicos, São Leopoldo, ano 1. n. 1, p. 67-68, 1961).

${ }^{21}$ Há, no final do século XVII, um ponto de desvio concernente à incorporação ibérica da tradição intelectual da Europa ocidental. Conforme MORSE, Richard. O espelho de Próspero: cultura e ideias nas Américas. São Paulo: Companhia das Letras, 1995. p. 28-29, as convulsões nos campos intelectual e teológico - e não havia uma separação entre intelectualidade e espiritualidade neste período - forçaram em Portugal e Espanha a uma reorientação do paradigma cultural oficial. É neste contexto que a Segunda Escolástica surge com toda a força. A Segunda Escolástica está ligada - até mesmo como sinônimo - à releitura dos textos de são Tomás de Aquino. Tal retomada tem, em Portugal, destaque. Mormente no que diz respeito à direção intelectual dos estudos, uma vez que o Ratio atque Instituto Studiorum - a "bíblia" jesuítica da educação formal - recomendava a observância fiel das doutrinas aristotélicas, reinterpretada que estavam em são Tomás. (Cf. MORSE, 1995, p. 29).

${ }^{22}$ GOMES, 2000, p. 137. Na sequência da citação: “[...] também a tradição tomista abunda, e mais do que pode julgar-se, na inspiração dessa magistral espiritualidade, que procura não apenas o saber, mas também o amor." 
Um dos livros mais conhecidos e respeitados no Brasil (e no mundo) sobre a História da Filosofia Cristã, é o de Philotheus Boehner (1901-1955) e Etienne Gilson (1884-1978), homônimo. Nele, Agostinho é apresentado como "mestre do Ocidente". Desde o Hiponense, conforme os autores: "Nenhum dos futuros sistemas cristãos irá poder ignorá-lo.” E concluem que, "todos, de um modo ou doutro, lhe sofreram o influxo. [...] Sua doutrina, perenemente viva, jamais cessou de reviçar a reflexão filosófica. ${ }^{23}$ " Também o medievalista Jacques Le Goff (1924-2014), tratando sobre a formação cultural da Europa do medievo, situando-a entre os séculos IV e $\mathrm{V}$, menciona dois autores que, segundo ele, moldaram o modelo moral/espiritual que se estenderia pelos séculos seguintes $^{24}$ : o primeiro mencionado é São Jerônimo, por sua tradução da Septuaginta para o latim (a Vulgata) e, depois deste, Agostinho, que se destaca, pro sua função pedagógica: "Depois de São Paulo, Santo Agostinho é o personagem mais importante para a instalação e o desenvolvimento do cristianismo. É o grande professor da Idade Média."25

(GOMES, 2000, p. 137).

${ }^{23}$ BOEHNER, Philotheus; GILSON, Etienne. Santo Agostinho, o mestre do Ocidente. In: História da

Filosofia Cristã. 2. ed. Petrópolis: Vozes, 1982. p. 139, 203. Ainda nas palavras de Boehner e Gilson: "Mais que nenhuma outra doutrina, a teologia agostiniana da história teve o efeito de transformar a face da terra. Ainda que o 'Sacro Império Romano de Nação Germânica' não fosse idéia do próprio Agostinho, ele não se originou sem uma interpretação política do seu conceito do Estado de Deus. Se, por hipótese, tivéssemos de prescindir da obra de Agostinho na história espiritual do Ocidente, depararíamos um hiato inexplicável entre o mundo atual e os tempos evangélicos." (BOEHNER; GILSON, 1982, p. 204).

${ }^{24}$ LE GOFF, Jacques. As raízes medievais da Europa. 2. ed. Petrópolis: Vozes, 2007. p. 30-31: "O surgimento da Europa [...] realizar-se-á através de dois fenômenos essenciais desse período dos séculos IV e V. O primeiro desses fenômenos é a elaboração, na linha da Bíblia e do Novo Testamento, do essencial da doutrina que os Padres da Igreja vão legar à Idade Média. [...] Insistirei em dois deles porque o seu peso será grande na elaboração de uma cultura europeia. O primeiro, São Jerônimo (c. 347-420), cuja vida situa-se ainda na interseção do Ocidente com o Oriente onde viveu durante longo tempo como eremita, não está completamente ligado ao futuro da Europa, mas o retenho aqui para esta obra essencial, a tradução para o latim a partir do texto hebraico da Bíblia por cima da tradução grega anterior dita dos Setenta e considerada defeituosa. Essa Bíblia latina vai impor-se a toda a Idade Média com diversas revisões, sendo a mais interessante a realizada no começo do século XIII pela Universidade de Paris sobre a recensão, no século IX, do conselheiro anglo-saxão de Carlos Magno, Alcuíno. É a Vulgata. Outro Padre da Igreja essencial é Santo Agostinho."

${ }^{25}$ LE GOFF, 2007, p. 31. Ainda conforme Le Goff: "Conservaram-se - além de numerosas perdas - 258 manuscritos das Confissões, 376 da Cidade de Deus e 317 da Regra. Esse legado da cultura antiga e cristã misturadas que os Padres da Igreja transmitiram à Idade Média e à Europa continua do século V ao VIII no contexto da fusão entre cultura antiga romana e evolução marcada pelas necessidades das populações que se tornaram bárbaras. Alguns grandes nomes emergem dessa situação, e Karl Rand os chamou de fundadores da Idade Média. Também se pode chamá-los de pais da cultura da Europa.” (LE GOFF, 2007, p. 32). No mesmo sentido, trazendo para o contexto brasileiro - e isto numa leitura super atual -, o luterano Ulrich Schoenbern, tendo em vista a influência da exegse histórico-literária que se deu com os "relatos de conversão" de Paulo e Agostinho, afirma que: "O Apóstolo Paulo, Agostinho e outros influenciaram estruturalmente os séculos seguintes e 'promoveram' o surgimento de uma tradição cujas pistas continuam até hoje." (SCHOENBORN, Ulrich. Fé entre História e experiência: migalhas exegéticas. São Leopoldo: Editora Sinodal, 1982. p. 210). 
Nos primórdios da formação cultural do Ocidente, há o que poderíamos chamar de uma "educação pelo livro", ilustrada por vasta iconografia ${ }^{26}$. Aí, Agostinho aparece como um vénérable maître ${ }^{27}$. "Atribui-se a Agostinho a criação do primeiro currículo e de uma primeira normatização do ensino. Santo Agostinho foi um dos primeiros filósofos a escrever um tratado especial sobre a educação, o De magistro. ${ }^{28 "}$ Assim, e como afirma Eduardo Antônio Jordão ao tratar sobre o papel de Agostinho enquanto educador: "Discorrer sobre a influência e importância de Agostinho no mundo Cristão Ocidental, tanto Católico como Protestante, parece desnecessário. ${ }^{29}$ " Desnecessário quando feito como prova e/ou relevância, porque óbvias.

\section{Pedagogia e catequese no De catechizandis rudibus}

Redigido em 405, o De catechizandis rudibus ${ }^{30}$ precede em sete anos o início da escrita do De civitate Dei (413-27); ou seja: temas referentes à ação de Deus na História Sagrada, espelhada na grande História do Mundo (secular), entrelaçando-as em uma narrativa paralela que caminha para uma resolução escatológico-teleológica ${ }^{31}$, ainda são, naturalmente, embrionários, e não tão bem desenvolvidos; mas claramente notados. É como faz Almir

\footnotetext{
${ }^{26}$ No sentido de "livros referencias" à educação das massas, no tempo comum - mas também, no aspecto cristão, com vistas à eternidade, quando cada um, individualmente, diante de Deus, terá o seu livro (de ações terrenas) aberto, pelo qual será julgado - conforme aparece em Apocalipse 20,12, tal referenciado por Michel Melot (MELOT, Michel. Livre,. Paris: L'œil Neuf Éditions, 2006. p. 195, etc.). Melot menciona um afresco da Igreja de Mantignac (em Lot), em que um demônio, chamado Ars Moriendi, tenta destruir o "livro da vida" de um cristão, para que, dele, no juízo, não haja memória - o que equivale à condenação; e afirma que, tal iconografia, neste sentido, foi precedida por Agostinho. Afirmação que é respaldada por Jean-Paul Suau: "Cette vague iconographique avait été précédée par sain Augustin. Pas de livre unique pour nous. Chacun aura le sien. C'est ainsi que les morts se pressent aux portes du ciel, exhibant devant eux leur livre ouvert, moment crucial de la pensée occidentale, contemporaine de l'invention de l'imprimerie, où s'exprime la responsabilité individualle dans un objet personnalisé." (SUOU, J.-P. Le Thème du livre individual des consciences sur les peintures murales du Jugement dernier à la fin du Moyen Âge. In: Enfer et paradis. L'au-delà art et la littérature en Europe. Actes du colloque de Conques, 1993-1994, Les Cahiers de Conques, n. 1, mars 1995, p. 147-75).

${ }^{27}$ O grosso volume do The classical moralists, compilado por Benjamim Rand e editado em 1909 pela Universidade de Cambridge, é bom exemplo. Cf. RAND, Benjamin. (Comp.). The classical moralists. Noston / New York / Chicago: Houghton Mifflin Company / The Riverside Press Cambridge, 1909. Agostinho é o décimo filósofo na lista, antecedendo, nas páginas dedicadas à Idade Média, Pedro Abelardo e Tomás de Aquino.

${ }^{28}$ SEVERINO, Antonio Joaquim. In: SANTO Agostinho e Santo Tomás de Aquino. São Paulo: ATTA Mídia e Educação / Paulus, 2009. 1 DVD (23:37 min.), color. (Col. Filósofos e Educação).

${ }^{29}$ JORDÃO, Eduardo Antônio. Agostinho: educação e fé na cidade de Deus. Petrópolis: Vozes, 2009. p. 11

30 "Sobre a catequização dos rudes", uma vez que Agostinho pensa naqueles que, "rudes", têm interesse em conhecer os rudimentos da fé, ou seja: instruir-se nisso, deixar de ser "rude", "não instruído". A tradução brasileira (Vozes), feita por Maria da Glória Novak (já em sua segunda edição), vai direto essencial: que é a formação do catecúmeno, com vista ao batismo na religião cristã. Não é literal, mas também não é equivocada.

${ }^{31}$ É o que, relacionado à questão da educação - e para não fugirmos ao tema -, nota Eduardo Antônio Jordão, na obra supracitada.
} 
Ribeiro Guimarães, destacando a individualidade dada ao sujeito na Grande História, situando-o dentro do drama cósmico: "É a partir da história de Deus na vida de cada um que será possível mostrar a ação de Deus na história do mundo. E essa iniciação cristã é, para Agostinho, eminentemente bíblica. O objeto da catequese é a história da salvação. ${ }^{32}$ " De fato. Também a obra, embora olhe para o passado, apontando para o futuro, é retrato de um tempo próprio, em que vem a lume com uma finalidade imediata:

A Instrução dos Catecúmenos sintetiza a pedagogia da fé e o que de melhor a Igreja desenvolveu na sua prática catequética em seus primeiros anos de existência. Este texto constitui-se em um documento que se refere à forma como a catequese era ministrada e retoma um tripé no qual se alicerçava a dimensão da prática catequética nesses primeiros tempos: instrução na fé, introdução na oração litúrgica e conversão de costumes. ${ }^{33}$

Mesmo depois das decepções que tem como professor das "ciências a que chamam liberais", em Tagaste (373), Cartago (374) e Milão (384) ${ }^{34}$, Agostinho continuou atuando não

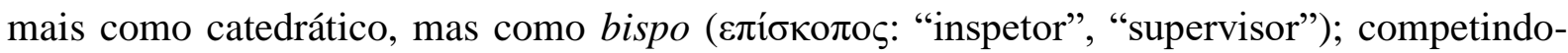
lhe, conforme o ofício: o pastorado da Igreja, o ensino da sua doutrina, a sacerdócio do culto sagrado e ministério do seu governo ${ }^{35}$ - e ele foi, como diz Marrou, "um dos raros pensadores cristãos que os não-cristãos sabem pelo menos que existe, e a quem concedem um lugar na evolução do espírito humano." 36

\footnotetext{
${ }^{32}$ GUIMARÃES, Almir Ribeiro. Prefácio. In: AGOSTINHO, Santo. A instrução dos catecúmenos: teoria e prática da catequese. 2. ed. Petrópolis: Vozes, 2005. p. 8.

${ }_{33}$ MEDEIROS, Márcia Maria. A instrução pelo riso em santo Agostinho. In: Acta Scientiarum. Education, Maringá, v. $32, \quad$ n. $2, \quad$ p. 185-91, 2010. Disponível em: <http://periodicos.uem.br/ojs/index.php/ActaSciEduc/article/viewFile/10429/10429>. Acesso em: 13 fev. 2011.

${ }^{34}$ Cf. Conf., IV, 1-16. A cátedra de retórica era um dos postos mais altos do magistério no Ocidente latino. As Ciências (ou Artes) Liberais, na época, concentravam-se no trivium (retórica, gramática e lógica), mas o que seriam as Sete Artes liberais da Idade Média - da soma com o quadrivium (aritmética, música, geometria e astronomia) -, já aparecem, de certo modo, em sua obra. Tomaram tal forma por volta do ano oitocentos, no império de Carlos Magno (747-814), no que representou a primeira tentativa de reorganizar o Império Romano. Resultaram, pois, de lento e constante amadurecimento, a partir de fontes pitagóricas, e talvez anteriores - com decisivas influências platônicas e aristotélicas. Depois de Agostinho, seriam rearranjadas metodologicamente por Marciano Capela (que escreveu entre 410 e 439), Severino Boécio (480-524) e Flávio Cassiodoro (490-580), até o bretão Alcuíno de York (735-804), que organizou a escola Carolíngea em Aix-en-Chapelle (ou Aachen), na Alemanha. Aí, "a tradição", da educação básica (trivial) nas Artes Liberais, conforme H. R. Loyn, "vinha diretamente de dos tempos clássicos, através dos escritos de Santo Agostinho." (LOYN, H. R. Artes Liberais. In: . Dicionário de Idade Média. Rio de Janeiro: Jorge Zahar Editor, 1997. p. 32).

${ }^{35}$ Cf. CIC, 375 §1. Embora, até 1917, o Codex Iuris Canonici não existisse - até então a Igreja Católica era governada por um conjunto disperso de normas, não unidas em um código comum (jurídicas, espirituais, temporais) -, o que se coloca, aí, em relação às funções do Bispo, segue o que já está assentado na tradição eclesiástica, e desde antes de Agostinho.
}

${ }^{36}$ MARROU, 1957, p. 181. 
Para Santo Agostinho, a educação deve ser um esforço de aprimoramento da essência humana para levar o homem à perfeição, e assim aproximá-lo de Deus. É, portanto, uma educação inteiramente voltada para o aprimoramento religioso e espiritual do homem, sem nenhuma finalidade material, política ou social. É uma pedagogia a serviço do desenvolvimento da fé e da espiritualidade do homem. ${ }^{37}$

Como pensador, e pelo modo como procurou conciliar a fé com o entendimento como pode ser visto em seus sermões, biografias (a que ele mesmo escreveu e a que foi escrita por são Possídio, morto por volta de 437), exposições de livros da Bíblia e tratados de filosofia -, é impossível não notar aí a sua posição em relação ao tema da educação ${ }^{38}$, intrinsecamente vinculada à catequese.

A vida e a obra do Hiponense estão entrelaçadas em uma longa jornada filosóficoexistencial-espiritual: do maniqueísmo ao ceticismo e, por fim, ao cristianismo, ao qual é convertido, depois da conturbada estadia em Milão. Foi aí que, em contato com o bispo Ambrósio, aprendeu o modo correto de abrir a Bíblia, para que ela se lhe tornasse inteligível; aí também teve contato com livros de neoplatônicos, que lhes falavam da realidade do mundo imaterial, e da não realidade física do mal; as cartas do apóstolo Paulo, por fim, dissiparam suas dúvidas relativas à fé e à graça ${ }^{39}$. O mestre da retórica tornara-se, agora, um gênio intelectual a serviço da fé. Convertido, "Agostinho mergulha no estudo das Escrituras e dela tira sua base para toda a vida, complementando a filosofia, tanto na teoria como na prática" 40 . "No mundo de Agostiniano, a educação cumpre sua tarefa quando auxilia o homem a atingir o estado espiritual e nele permanecer. ${ }^{41}$ " Como em sua própria experiência - ele acredita -, é após o entendimento da mensagem da Escritura que nasce o cristão, por vontade de Deus e ação do Espírito. “A primeira observação a ser feita quanto a essa busca e empresa é [...] tomar conhecimento dos Livros santos. Se, a princípio, não se conseguir apreender o sentido todo, pelo menos fazer a leitura e confiar à memória as santas palavras. ${ }^{42}$ " "Na verdade", diz Teresinha Oliveira,

\footnotetext{
${ }^{37}$ SEVERINO, 2009.

${ }^{38}$ Cf. SALES, 2009. p. 19.

${ }^{39}$ REALI; ANTISERI, 1990, p. 431.

${ }^{40}$ OLIVEIRA, Terezinha. Agostinho e a educação cristã: um olhar da história da educação. In: Notandum, Portugal, p. 7, 2008. Disponível em: <http://www.hottopos.com/notand17/terezinha.pdf>. Acesso em 20 de jan. 2011.

${ }^{41}$ JORDÃO, 2009. p. 61.

${ }^{42}$ De doc. Christ, II, 9,98.
} 
Agostinho apresenta diversos aspectos que julga serem elementos essenciais para se compreender as palavras contidas nas Escrituras. A nosso ver, apresenta, de fato, um roteiro de como se deve proceder para ser cristão. Do seu ponto de vista, a conversão é um processo de aprendizagem. No seu tempo, em geral, não se nascia cristão, mas se tornava, pela aceitação da doutrina. ${ }^{43}$

Se ser cristão é um tornar-se, então o caminho exige um método - que pode, às vezes, não ser bom, e, por isso, é preciso "jogo de cintura" para adaptá-lo às diversas situações. "Se nos entristece o fato de que os ouvintes não nos acompanham", ele escreve a Deogratias, "somos obrigados a descer, de alguma forma, das alturas do pensamento e demorar-nos na lentidão das sílabas... tão longe, tão baixo! ${ }^{44 "}$ Trata-se, para ele, primeiramente, de um esforço: por amor a Deus, por amor à sua Igreja, por amor àqueles e aquelas que dela fazem parte (ou desejam fazê-lo, através do batismo), e à doctrina christiana; esta, bem fundamentada, é trincheira na luta contra as heresias, e castelo forte que abriga a fé.

Diferentemente do que ocorre em seus primeiros diálogos, no De catechizandis praticamente não há especulações filosóficas, rebuscadas análises filosófico-filológicas; tratase de um manual altamente prático, fundamentado na prática do seu autor, e para a prática de um agoniado Deogratias, ávido por bem conduzir seus ouvintes aos rudimentos da fé; para que, em tal matéria, não sejam mais rudes, mas excelentes.

\section{Esboço histórico-analítico do De catechizandis rudibus}

No final do século IV, não mais prevalecia a catequese moral, própria de textos clássicos como Didaqué ${ }^{45}$, Carta a Diogneto - embora ignorada pelos autores da Patrística e do Medievo ${ }^{46}$-, separatas de obras dos Pais Apostólicos, etc ${ }^{47}$. Fortaleciam-se, desde Irineu

\footnotetext{
${ }^{43}$ OLIVEIRA, 2008, p. 6.

${ }^{44}$ De cat. rud., I, 10,15.

${ }^{45}$ Cf. DIDAQUÉ: o catecismo dos primeiros cristãos para as comunidades de hoje. 6. ed. São Paulo: Paulus, 1989. $31 \mathrm{p}$.

46 "Os críticos modernos, em sua maioria, datam-na da segunda metade do século II. Alguns o atribuem a Panteno, predecessor de Clemente de Alexandria [c. 150-215] no ensino filosófico em Alexandria e, portanto, refletindo um ensinamento tipicamente alexandrino." (FIGUEIREDO, Fernando A. Introdução. In: CARTA a Diogneto, A. 2. ed. Petrópolis: Vozes, 1984. p. 7). Em relação à autoria de Panteno, ver: MARROU, Henri Irénée. A Diognète. Paris: Les Ed. du Cerf, 1955. p. 266s. (Sources Chrétiennes, 33 bis). Ver ainda: PETERS, S. Gabriel. Lire les Pères de l'Église, Cours de Patrologie. Paris: Desclé de Brouwer, 1981. p. 251-65.

${ }^{47}$ Cf. TURCK, André. Evangélisation et catéchèse aux deux premiers siècles. Paris: Ed du Cerf, 1962.
} 
de Lião (c. 130/40-200/2) ${ }^{48}$, modelos mais sistemáticos, ou “corpos doutrinários" que visavam resumir a História da Salvação (Heilsgeschichte, na expressão dos teólogos alemães) ${ }^{49}$, “do Gênesis aos dias atuais". "A história da salvação [...] é o processo da economia de Deus, realizada pela recapitulação de todas as coisas em Cristo; é ela espaço da educação progressiva do homem. ${ }^{50 "}$ O De catechizandis rudibus, neste ponto em particular, segue a tradição ireniana - como também se nota em Peregrinação de Etéria, escrito no IV século ${ }^{51}$. $\mathrm{O}$ antigo modelo de catequese, fixado desde o início do século III, abrangia uma tríplice e limitada dimensão que procurava responder às perguntas: que é a fé cristã?, como orar corretamente?, como andar na fé (agir moralmente)? "No Império Romano não havia propriamente um sistema organizado e público de educação. A educação era tarefa familiar, desenvolvida através de mestres particulares e não havendo a preocupação de uma educação destinada a toda a população." 52

O De catechizandis é uma obra datada, mas vai além da simples datação, atualizando questões e tornando-se "uma pequena obra prima, [...] por suas bases teológicas e antropológicas, pelo espírito que o anima pode ser apontado como o mais perfeito documento de catequético dos primeiros séculos. ${ }^{53}$ " Na pedagogia do De catechizandis rudibus, até certo

\footnotetext{
48 "Na sua luta contra a heresia, Irineu expõe os princípios da sã interpretação das Escrituras: a regra da fé da Igreja para quem quer permanecer estritamente fiel, no respeito à Tradição. Apresenta a justo título resumo da Escritura de onde ela provém. Em face ao gnosticismo herético, Irineu rejeita todo esoterismo: a fé da Igreja não é por nada gnose reservada a elite de iniciados; pertence a todos os fiéis, desde os simples e pequenos. E mais grave ainda: os heréticos recusam a revelação divina e, portanto, a salvação que nos advém pela encarnação que recapitula a humanidade, pondo em comunhão com Deus." (PETERS, 1981, p. 313).

${ }^{49}$ No livro dos Atos dos apóstolos, dois textos são exemplares: os enormes discursos de Estevão, mártir (7, 1-53) e do apóstolo Paulo (13, 13-41). A História da Salvação, nos exemplos, e sob certos limites, resume e esboça a ação de Deus na História, em favor dos homens, na intenção de salvá-los.

${ }^{50}$ RIBEIRO, Helcion. Introdução. In: IRINEU DE LIÂO. Contra as heresias: denúncia e refutação da falsa gnose. 2. ed. São Paulo: Paulus, 1995. p. 20. (Col. Patrística, 4). "A obra de Irineu ocupa hoje lugar especial na história do pensamento cristão, não apenas por seu caráter de síntese completa, mas também pela perspectiva e globalidade dadas à história da salvação." (RIBEIRO, 1995, p. 25). A História da Salvação, em Irineu, procura "ensinar a doutrina da Igreja, transmitida sem descontinuidade pelos apóstolos e seus sucessores, de modo preciso e fiel, combatendo os erros todos." (RIBEIRO, 1995, p. 19), principalmente os do gnosticismo - além das heresias da época: ebionitas, valentinianos, marcionitas, montanistas, nicolaítas, ofitas, setitas, cainitas, dentre outras.

51 "Começando no Gênesis", ela diz, "percorre inteiramente as Escrituras." (Pereguinação de Etéria, n. 46, 2; PEREGRINAÇÃO de Etéria: liturgia e catequese em Jerusalém no século IV. 2. ed. Petrópolis: Vozes, 2004. p. 117). Nos final do século IV, peregrinos chegam à Terra Santa vindos dos quatros cantos do mundo cristão. Entre eles, Etéria, que deixou o testemunho escrito sobre sua peregrinação, um diário. Dois terços do manuscrito se perderam, por isso pouco se sabe sobre ela, senão que visitou Jerusalém entre 381 e 384, vindo da Galiza ou Aquitánia, desejando seguir os passos do Cristo, reviver pela oração a História da Salvação em seus locais sagrados. O texto esteve perdido durante 700 anos. A única cópia existente do manuscrito era uma do século XI, conservado em Arezzo, onde, esquecida, seria redescoberta em 1884.

${ }^{52}$ SEVERINO, 2009 [DVD].

${ }^{53}$ PAIVA, Hugo de V. Introdução. In: AGOSTINHO, Santo. A instrução dos catecúmenos: teoria e pratica da catequese. 2. ed. Petrópolis: Vozes, 2005. p. 10.
} 
ponto inovadora, quatro etapas antecediam a entrada na vida cristã: 1) educação do povo em geral, os rudes accedentes: aqueles que frequentavam as pregações, procurando instruções sobre os rudimentos da fé, os rudes; 2) educação dos catechumeni (no Oriente), ou auditores (no Ocidente), que eram os candidatos ao batismo, os catecúmenos ${ }^{54}$; 3) educação dos competentes (ou electi, ou photizomenoi: "os que serão iluminados"), os ex-auditores, excatechumeni; 4) educação dos neófitos que, após serem batizados na noite pascal, recebiam instruções sobre os mistérios da fé e os sacramentos. Em todas essas etapas eram combatidas as heresias, ao mesmo tempo em que se apresentavam as bases da doctrina christiana. ${ }^{55}$

A catequese leva a boa-nova aos homens tais como são. E isto por uma dupla exigência, pedagógica e teológica. A História da Salvação pessoal e a da humanidade estão em estreita relação com a experiência bíblica de salvação. Por isso o catequista levará o homem que quer encontrar-se com Deus a primeiro encontrar-se a si mesmo. ${ }^{56}$

Esse encontro interior, antes de tudo, é um encontro em que o sujeito se reconhece, procura se reconhecer, perguntando: "Quem sou eu? O que me tornei? ${ }^{57 "}$ Somente assim poderá “conhecer" o outro, e o mundo.

Até o capítulo X da primeira parte, o De catechizandis está dividido em dois assuntos principais: como a narração da História da Salvação deve ser conduzida (sistemática); como transmitir preceitos e exortar sem negligenciar o amor (didática). É a parte mais teóricometódica da obra. Daí em diante, novo assunto é colocado: como estar alegre e transmitir conteúdos no mesmo espírito (prática). O Hiponense ilustra sua metodologia redigindo um

\footnotetext{
${ }^{54}$ Também em Hipólito de Roma (c. 170-236), o mais importante teólogo do século III, há uma descrição de como era a instrução dos catecúmenos em seu tempo. Cf. HIPÓLITO de Roma. Tradição apostólica. 2. ed. Petrópolis: Vozes, 2004. p. 56s.

${ }^{55}$ Cf. JORDÃO, 2009, p. 61. A metodologia agostiniano de combate às heresias, ainda conforme Jordão, tem sido "até agora pouco explorada pela literatura pedagógica, por não tratar estritamente de educação, métodos educativos ou concepções de aprendizagem. Ainda assim, o embate que Agostinho travou em seu tempo para a formulação da doutrina cristã, quando bem fundamentado, contribui para compreensão de seu significado educacional, mesmo que em sentido mais amplo." (JORDÃO, 2009, p. 104).

${ }^{56}$ PAIVA, 2005, p. 20. Noutra parte, Paiva dizia: "Se ainda é permitido recorrer às categorias clássicas da escolástica, pode-se distinguir [Paiva, nesse particular, comenta a Parte III de De cat. rud., de Agostinho] em catequética um duplo aspecto: um material ou o conteúdo; outro formal ou a maneira de transmitir." (PAIVA, 2005, p. 19). A pedagogia de Agostinho tem, ainda, as marcas da Antiguidade (Platão, Aristóteles, os estoicos), mas é, sob muitos aspectos, como poderemos ver, inovadora.

${ }^{57}$ Conf., IX, 1,1: "Quem sou eu e como sou eu? Que mal há que não o tenham sido os meus atos, ou, se não os meus atos, as minhas palavras, ou, se não as minhas palavras, a minha vontade?" O reconhecimento de si mesmo é o reconhecimento de uma condição de limite e de carência: "Que sou eu para mim sem ti, senão um guia que conduz ao abismo? Ou que sou eu, quando estou bem, senão uma criança que suga o teu leite ou frui de ti como alimento que não se corrompe? E quem é o homem, qualquer homem, sendo homem? Mas zombem de mim os fortes e os poderosos, e nós, fracos e desamparados, confessemo-nos a ti." (Conf., IV, 1,1).
} 
modelo catequético que, embora seja seu, também poderia ser utilizado por Deogratias, que deveria adaptá-lo, fazendo acréscimos e/ou cortes que julgasse adequados à sua própria necessidade. A base da redação, pontuada de exemplos, é a própria experiência de vida e ensino do Bispo de Milão. Os temas da primeira parte são retomados, agora ilustrados em narrativas que têm o objetivo de pôr em prática o que se disse, antes. Deogracias deve ser capaz de, partindo daí, desenvolver seu próprio estilo, visando o feedback orador/auditório, a fim de que todos saiam ganhando.

\subsection{Como a narração da História da Salvação deve ser conduzida}

Palavras sonoras são mais lentas que o pensamento. Por isso, e antes de querermos educar a outrem, é preciso que sejamos educados em ambos: palavra (modo de falar) e pensamento (voz interna acerca do que desejamos falar ou omitir). Dizendo-se entristecido de que sua "língua não baste ao meu coração", o Hiponense deseja,

que aquele que me ouve entenda tudo o que eu entendo, mas percebo que minhas palavras não podem consegui-lo: o entendimento penetra a alma como rápido clarão enquanto que a expressão é lenta e longa, e muito diferente daquele. Enquanto se desenvolve esta, já aquele se fechou no seu segredo... embora, maravilhosamente, imprima na memória algumas marcas que perduram durante a enunciação das sílabas. ${ }^{58}$

Trata-se de um tema, e um problema, já presente no De magistro, e que aqui reaparece, de modo a ilustrar a dificuldade em conciliar pensamento e palavra e, mais, fazer com que ambos sejam compreendidos por aquele que ouve. Como as palavras de mesmo significado têm, em outras línguas, sinais sonoros próprios - como "ira", no exemplo -, assim também o entendimento acerca das mesmas, a depender do espírito de cada um; de modo que, o que ensina, nada pode fazer senão indicar caminhos, incitar o ouvinte a - solução do $D e$ magistro e do De vera religione $e^{59}$ - voltar-se para si mesmo e, aí, saber da verdade que habita

\footnotetext{
${ }^{58}$ De cat. rud., I, 2, 3.

${ }^{59}$ De vera rel., 39, 72. Essa confirmação da verdade interior, que aparece em muitas obras de Agostinho, também pode ser encontrada em De mag., XIII: “[...] mesmo nas coisas que são intuídas pela mente, em vão todo aquele que as não pode intuir, ouve as palavras do que as intui, à parte ser útil acreditá-las enquanto se ignoram. Todo aquele porém que as pode intuir - esse interiormente é discípulo da Verdade, e exteriormente é juiz daquele que fala, ou melhor, da mesma locução, pois muitas vezes sabe as coisas que se disseram, quando as ignora aquele mesmo que a disse". A Verdade interior, aquela da iluminação, é, sempre, verdade do Real. A Verdade interior, portanto, julga sempre a "verdade" exterior, fazendo-a adequar-se a si ou, de modo contrário, condenando-a como erro. Assim, nas palavras de Adeodato: De mag., XIV: "Quanto a mim, advertido pelas tuas
} 
em seu interior. Não há ensino (pela ação do mestre exterior), mas aprendizagem (do discípulo, quando encontra o mestre interior):

Nem se pode externar, ou desdobrar ao entendimento dos ouvidos, pelo som da voz, as marcas que a inteligência imprime tão clara e abertamente na memória como é aberto e claro o semblante: as marcas estão dentro - na alma - e o semblante está fora, no corpo. E se o som da língua nem mesmo se assemelha à impressão na memória, devemos meditar no quanto dista do alcance da inteligência. ${ }^{60}$

A narração da História da Salvação, assim, e confiando-se na ação do Espírito, é o que pode conduzir o ouvinte ao mestre interior, e alcançar sua plenitude teologal. Plenitude, no caso, significa completude: início (Queda), meio (História de Deus com o seu povo, até o Cristo e a Igreja) e fim (o retorno do Cristo para levar os seus à Nova Jerusalém). Ela é completa "quando o catecúmeno é instruído a partir do início da Escritura [...] até os tempos atuais da Igreja. ${ }^{61 "}$ A meta é mostrar como, tanto no Velho como no Novo Testamento, a caridade é exaltada e, por todos os cantos, anunciado o Cristo. "Em tudo, sem dúvida", ele diz, "não somente devemos observar o fim do preceito - a caridade [com a qual fomos amados, pela qual devemos amar] - para que se reflita em tudo o que dizemos. ${ }^{62}$ " Sombra, tipo, figura; sim, "no Antigo Testamento esconde-se o Novo, e no Novo encontra-se a manifestação do Antigo. ${ }^{63 "}$ A História da Salvação é a narrativa de como Deus, por todos os séculos, está com o seu povo, conduzindo-os conforme seu santo desígnio.

Do capítulo XVI ao XXIV, a começar pelos motivos da encarnação do Verbo (por causa da Queda, como relatada no Gênesis), a narrativa é linear e progressiva, até a atualidade da Igreja e, daí, até o dia do Juízo Final, em que os justos estarão todos juntos na civitas Dei.

palavras, aprendi que o homem, pelas palavras, não é mais que incitado a aprender, e que é de muito pouco valor o fato de que grande parte do pensamento de quem fala se manifesta pela locução. Se realmente se dizem coisas verdadeiras, só o ensina Aquele que quando nos falavam de fora, nos advertiu de que Ele habitava no interior. Eu o amarei desde agora tanto mais ardentemente, quanto mais estiver adiantado em aprender." Se a famosa frase do carismático Jean Piaget (1896-1980): "O professor não ensina, mas arranja modos de a própria criança descobrir. Cria situações-problemas" (PIAGET, Jean. Où va l'éducation?. Paris: Denoël / Gonthier, 1948. p. 10) é, de certo modo, resumo de sua metodologia psico-pedagógica, é, também, inequivocamente, reflexo da Doutrina da Iluminação interior, de Agostinho - como aparece no De magistro (389) e, depois, no De vera religione (38991); este, dirigido contra os maniqueus, descreve com minucias o processo de interiorização, constituindo-se em importante chave para compreensão do pensamento agostiniano.

${ }^{60}$ De cat. rud., I, 2,3. A referência ao semblante e à memória falha, dele, que é tão próximo do "lugar do pensamento", é retirada de uma alegoria do apóstolo Paulo (1Cor., 13, 12), e também na epístola de Tiago (1, 234).

${ }^{61}$ De cat. rud., I, 3,5.

${ }^{62}$ De cat. rud., I, 3,6.

${ }^{63}$ De cat. rud., I, 4,8. 
É uma só História, do começo ao fim, que é a eternidade: “Todos os fatos que agora vês na Igreja de Deus, [...], foram preditos há séculos. ${ }^{64 "}$ Assim, e para animar a Deogratias, o Hiponense lhe encoraja: "Crê a partir do exame de ti mesmo: haverás de existir - depois de ter existido, porque agora vês que existes - embora não tenhas existido antes. ${ }^{65}$ " O caminho até a Nova Jerusalém não é fácil, e é preciso, além dos cuidados dispensados aos outros, cuidado para consigo mesmo: precaução contra os ímpios, os heréticos, os falsos cristãos, etc.

\subsection{Como transmitir preceitos e exortar sem negligenciar o amor}

A concordância entre os testamentos não somente tenciona calar os que veem um Deus diferente (no agir de lá, no agir de cá), mas também fazer tudo afluir para a realização de um plano salvífico pré-determinado, manifesto no amor que doa gratuitamente (graça), expondo a miséria e a arrogância do que não sabe (e nem pode) retribuir em igual medida, tornando-o humilde e dependente. Máxima do dito, o amor divino torna-se paradoxo contra o entendimento não conduzido pela fé: “Grande miséria é sem dúvida um homem arrogante: misericórdia maior é, porém, um Deus humilde! ${ }^{66 "}$ O que segue, de imediato, é o que poderíamos chamar de "imperativo categórico agostiniano". Este, imperativíssimo, re-afirma o amor cristão como a maior das três virtudes teologais: "Por esse amor, portanto, como por um alvo proposto, pelo qual digas tudo o que dizes, o que quer que narres faze-o de tal forma que aquele que te ouve, ouvindo, creia e, crendo, espere e, esperando, ame. ${ }^{67 "}$ É o mesmo espírito de outra máxima sua, famosa: "Ama e faz o que quiseres." 68

Ao colocar o primado do amor (caridade), e este à luz do mestre interior, o Hiponense estabelecerá o fundamento que, da Patrística até a Reforma, com Martinho Lutero (1483-

\footnotetext{
${ }^{64}$ De cat. rud., II, 27,53.

${ }^{65}$ De cat. rud., II, 25,46.

${ }^{66}$ De cat. rud., I, 4,8.

${ }^{67}$ De cat. rud., I, 4,8 .

${ }^{68}$ In Ioan. Evang., 7, 8. Ou: “Ama, e assim não poderás fazer senão o bem” (In Ioan. Evang., 10, 7). Santiago Sierra Rubio, tratando sobre a ação moral de Cristo, enfatiza a causa precípua do advento de Cristo como sendo uma exaltação ao/do amor (Cf. RUBIO, Santiago Sierra. Patria y camino: Cristo en la vida y en la reflexión de San Agustín. Madrid: Ediciones Religión y Cultura, 1997. p. 103-05). O texto utilizado por Rubio é o que encontramos em De cat. rud., I, IV,7: "Que maior causa pode haver da vinda do Senhor senão mostrar-nos Deus o seu amor? E brilhantemente o demonstrou, pois éramos ainda pecadores quando Cristo morreu por nós! ...Porque a caridade é o fim do mandamento e o pleno cumprimento da Lei: para que nós também nos amemos uns aos outros e, assim como Ele ofereceu por nós a sua vida, assim também demos a nossa vida pelos nossos irmãos. [...] O amor é efetivamente mais grato quando não é perturbado pela aridez da necessidade, mas deriva da bondade fecunda. Aquele provém da miséria, este da misericórdia."
} 
$1546)^{69}$, será dominante, mudando apenas com Immanuel Kant (1724-1804), no século XVIII. Kant fundamenta sua ética (lei moral) no dever ${ }^{70}$, conforme o imperativo categórico: "Age de tal forma..." como se... (als ob...). Em Agostinho, o "faze-o de tal forma que aquele que te ouve...", antecipa-o ${ }^{71}$. Neste, prevalece o idealismo (neoplatônico), e fé confiante ${ }^{72}$; naquele, o objetivismo da simples razão, sem o auxílio da fé.

Assim, e dentre outras, o candidato ao catecumenato deve ser interrogado sobre suas reais motivações: se são guiadas pela caridade, pela doação de si mesmo em favor do outro (seu próximo), e não em busca de humanos privilégios. E como "a fé não está no corpo que se inclina, mas na alma que crê",73, assim também a voz exterior, que não deve prevalecer sobre a interior, onde cada um sabe o que foi, é, deseja ser, realmente. Nisto, tanto aos rudes quanto aos doutos, é preciso fazê-los

\footnotetext{
${ }^{69}$ A ética cristã, conforme Stanley Grenz, é modelar em Agostinho "como Amor a Deus", em Tomás de Aquino "como realização de nosso objetivo", e em Lutero e nos demais reformadores clássicos "como obediência de quem crê". (Cf. GRENZ, Stanley. Propostas de modelos cristãos. In: . A busca da moral: fundamentos da ética cristã. São Paulo: Vida, 2006. p. 149-92. [Col. Acadêmica]).

70 "Muitos filósofos viram a moralidade de uma maneira muito diferente. Alguns deles [dentre os quais, Agostinho] pensavam que havia uma lei moral objetiva, mas que esta dependia da vontade de Deus. Outros pensavam que a moralidade tinha algo a ver com a razão, mas que o exercício da razão consistia inteiramente em promover algum objetivo, como a própria felicidade ou o bem estar da sociedade [aí se incluem desde Aristóteles até os epicureus e estóicos]. Kant rejeita essas idéias, porque elas fazem a moralidade depender de algo exterior a ela mesma: a vontade de Deus, ou o desejo de promover o bem-estar. Ele rejeita igualmente a idéia de que a moralidade é apenas o desenvolvimento natural de certos sentimentos que pertencem à nossa natureza humana. Isso não seria compatível com seu caráter intrinsecamente racional." (WALKER, Ralph. Kant: Kant e a lei moral. Trad. de Oswaldo Giacóia Junior. São Paulo: Editora UNESP, 1999. p. 7. [Col. Grandes Filósofos]).

${ }^{71} \mathrm{O}$ resultado da ação moral, fundamentada no princípio do amor, portanto, deságua nas três virtudes teologais (cf. 1Co 13, 13). No original latino: "[...] uti ille [...] audiendo credat, credendo speret, sperando amet." Para a moral do dever, em Kant, ver: KANT, Immanuel. Grundlegung zur Metaphysik der Sitten. Karl Vorländer (Org.). Hamburg: Der philosophischen Bibliotek, 1965. p. 512. Bd 6 [BA 52]. "Toda ação exige a antecipação de um fim, o ser humano deve agir como se (als ob) este fim fosse realizável. [...] Segundo Kant, a noção de felicidade, que fundamenta por exemplo as éticas do período helenístico, como a estóica e a epicurista, é insuficiente como fundamento da moral, porque o conceito de felicidade é variável, dependendo de fatores subjetivos, psicológicos, ao passo que a lei moral é invariante, universal; por isso seu fundamento é o dever." (MARCONDES, Danilo. Iniciação à História da Filosofia: dos pré-socráticos à Wittgenstein. Rio de Janeiro: Jorge Zahar Ed., 1998. p. 213). As semelhanças, cada qual à sua proporção, como se vê, são enormes. As semelhanças e diferenças entre os "imperativos" da ética de Agostinho e de Kant, que fogem ao nosso tema, foram tratadas em um artigo de: HARE, John E. Augustine, Kant, and the Moral Grap. In: MATTHEWS, Gareth B. (Ed.). The augustinian tradition. Berkeley, Los Angeles, London: University of California Press, 1999. p. 251-62.

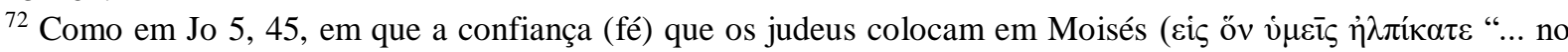
qual vocês esperam") opõe-se à confiança (fé) no Cristo. No texto, é o próprio Cristo quem fala, segundo João. “À forma especificamente neotestamentária da fé como aceitação do kerygma, acrescentam-se as notas do Antigo Testamento da relação viva com Deus: confiança e esperança (Hb 11, 9-11, 13-17; Rm 4, 17-20; 1 Pe 1, 5-9), fidelidade e obediência (2Tm 4, 7; 1Pe 5, 9; Ap 2, 13; At 6, 7; Rm 1, 5: Gl 5, 6s; 1Tm 2, 15)." (SECKLER, M. Fé. In: Dicionário de teologia: conceitos fundamentais da teologia atual. 2. ed. São Paulo: Edições Loyola, 1983. p. 194. v. 2). "Fé confiante", aqui, tem este mesmo sentido.

${ }^{73}$ De cat. rud., I, 5,9.
} 
saber que as idéias devem ser postas acima das palavras, assim como a alma é posta acima do corpo. [...] Saberão também que não há voz para os ouvidos de Deus, mas sentimentos da alma. [E] a palavra forense pode algumas vezes, talvez, ser chamada uma boa dicção, nunca porém uma bênção. ${ }^{74}$

O trato fraterno, fundamentado no amor, acima de tudo, tenciona evitar o erro do juízo, que costuma ser apressado, lançado sobre situações e aspectos vários. Do erro do juízo é que se segue o erro da ação. Nova máxima: "Imita os bons, tolera os maus e, porque não sabes o que será amanhã o que hoje é mau, a todos ama. ${ }^{75}$ " Exercício da paciência, o princípio do amor, categórico, torna-se aplicável a todos, em qualquer tempo, em qualquer parte. Mais que beneficiar ao meu próximo $(\text { proximus })^{76}$, por amá-lo, é a mim mesmo que beneficio embora minha ação não deva ser realizada em benefício de mim mesmo (Eu). ${ }^{77}$

\subsection{Como estar alegre e transmitir conteúdos com alegria}

É preciso que retomemos o que foi dito acerca do capítulo $\mathrm{X}$, antes de entrarmos na segunda e última parte da obra. No terceiro parágrafo do capítulo $\mathrm{X}$ do De catechizandis rudibus, Agostinho dá por encerrada a parte teórico-metodológica, dizendo que, "sobre as normas de exposição do assunto da catequese na instrução dos que vêm tornar-se cristãos, cumpri suficientemente, parece-me, o que havia prometido ${ }^{78 \% ;}$ seguem-se os conselhos referentes ao modo de expor assuntos sem enfastiar o auditório - que pode ter vários motivos (físicos ou psicológico/espirituais) para estar assim -, e sem negligenciar o amor: "Talvez desejes um modelo de exposição. Talvez desejes que eu te mostre com a própria obra como pôr em prática o que aconselhei" ${ }^{\prime 79}$, e o faz, como visto. É neste processo, e para ele, que o

\footnotetext{
${ }^{74}$ De cat. rud., I, 9,13.

${ }^{75}$ De cat. rud., II, 27,55.

${ }^{76}$ Como em De cat. rud., II, 26,50: “Assim também não deve entender próximo carnalmente: próximo é todo aquele que poderá vir a estar com ele [o catecúmeno] na Cidade santa - quer possa, quer não possa ainda vê-lo."

77 "Aquele que ama expressa a sua totalidade amorosa no outro. E ao fazê-lo, surge o respeito mútuo. No respeitar-se mutuamente, cada um assume o outro como prolongamento de si mesmo. O amor, como prolongamento de si mesmo, é capaz de transformar o outro. Percorrido esse caminho, surge a felicidade que é também o grande desejo de Agostinho, porque para ele o amor dá significado à existência humana." (GOMES, Rogério. O amor em Santo Agostinho antes de sua conversão. Disponível em: <http://www.3pinformatica.com.br/redemptor/fotos/fotos/admin/imagens/revistas/pdf/amorhumanoemsantoagost inho.pdf>. Acesso em 03 de fev. 2011. p. 10).

${ }^{78}$ De cat. rud., I, 10,14.

${ }^{79}$ De cat. rud., I, 10,14.
} 
Hiponense propõe um modelo de "educação pelo riso", como apontado no artigo da Márcia Maria Medeiros. ${ }^{80}$

Nas longas exposições da História da Salvação, é capaz de o tédio se instalar no auditório e, nisso, haver desvios de atenção, perda de interesse pelo tema e desistência (evasão). Para combater tudo isso: alegria. Como ter um auditório alegre? Para que se tenha um auditório alegre, o orador há que, antes, achar-se também alegre.

A falta da alegria durante a instrução pode ocorrer por, pelo menos, seis causas comuns: 1) percepção do orador de que os ouvintes não lhe acompanham no raciocínio; caso em que ambos, orador e auditório, podem enfadar-se; 2) acanhamento ou imperícia metodológica do orador, que prefere ler a falar; 3 ) repetições forçadas: quando o auditório não entende, e faz-se necessário o ministrante voltar ao mesmo tema, repetidamente ${ }^{81}$; seja quando o orador é repetitivo, em um tema muito explorado ou já muito claro; 4) “outras vezes será a inércia dos ouvintes, que se refugiam no temor da religião, no respeito humano, no desprezo ou no cansaço pelas longas horas em pé"82; 5) pode ocorrer de o catequista, por algum excesso de tarefas, faltar à reunião, quebrando a sequência das preleções - e principalmente se a falta é corriqueira; 6) por fim, pode ocorrer de o catequista estar psicologicamente perturbado, por alguma falha moral, algum pecado, algum escândalo na comunidade. Estas são, para Agostinho, as seis causas mais comuns e que podem produzir enfado ao orador e/ou ao seu público. Depois de apresentar a doença, o Hiponense propõe a cura; e o faz do capítulo X ao XIV, apresentando "remédios contra" as causas, uma a uma.

Quem desejasse aplicar tais conselhos nos dias de hoje, teria que adaptá-los, naturalmente - a exemplo do que faz o Pe. Miguel Lucas, no seu A arte de ensinar: ensine como Santo Agostinho, de $1984^{83}$. O De catechizandis, todavia, e como diz Hugo de V. Paiva, “em seu conjunto e, sobretudo, por suas preocupações de ordem psicológica, social, teológica

\footnotetext{
${ }^{80}$ Cf. MEDEIROS, 2001, p. 185-91.

81 "Com efeito, quantas vezes o professor deve sentir-se enfadado por ter que ensinar as mesmas coisas a cada novo semestre, a cada nova aula, a cada nova turma? Ora bem, como evitar este enfado? Segundo Agostinho, não há outro modo de se renovar o ensino a não ser por meio de uma identificação que se dá, justamente, na simpatia professor/aluno. Nesta dinâmica, os dois passam a ter os mesmos sentimentos e a alegria do aluno passa então a ser a alegria do professor." (LAET, Sávio. A educação em Agostinho. Disponível em: <http://www.filosofante.org/filosofante/not_arquivos/pdf/Educacao_Agostinho.pdf>. Acesso em 17 de jan. 2011).

${ }^{82}$ PAIVA, 2005, p. 23. A catequese da época, como bem ilustrada no filme Santo Agostinho (1972), de Roberto Rosseliline, era longa, e ouvida de pé. Cf. SANTO Agostinho. Dir. de Roberto Rossellini. São Paulo: Paulinas / LUCE / Versátil Home Vídeo, 2007. 1 DVD (115 min.), fullscreen, color.

${ }^{83}$ LUCAS, Miguel. A arte de ensinar: ensine como Santo Agostinho. 3. ed. São Paulo: IBRASA, 1984. 115 p. (Col. Biblioteca Didática, 32). Na obra, o autor recolhe preceitos e recomendações didáticas, extraídas das várias obras do Hiponense, dentre as quais o De catechizandis rudibus, fartamente usada.
} 
[eles] tem valor permanente. ${ }^{84 »}$ O próprio Agostinho não via seu manual como coisa pronta, acaba; eram sugestões sujeitas ao aperfeiçoamento, conforme a dinâmica daquele ou daquela que fosse usá-lo, dando vida e cor à forma estática da escrita - como diz a Deogratias:

Já gora estarás pedindo talvez, com insistência, aquilo que te devo porque te prometi. E não me desgostará desenvolver, para que o consideres atentamente, um modelo de exposição catequética como se eu mesmo instruísse alguém. Antes porém quero que tenhas presente no espírito que uma coisa é a intenção daquele que redige pensando em um futuro leitor, e outra a do que fala dirigindo-se a um interlocutor presente. ${ }^{85}$

E o que segue, após as advertências sobre aqueles que compõem o auditório - se são mesmo cristãos, se têm boas intenções, etc. -, é um modelo particular, do Hiponense, de expor a História da Salvação, como teorizado nos pontos anteriores, e como já demonstramos.

\title{
A título de conclusão
}

\section{Para Garry Wills:}

\begin{abstract}
Agostinho pretendia aprender tanto quanto ensinar quando falava com seus companheiros crentes. A sua pronta reação ao humor da audiência, a sua improvisação quando um texto não estava funcionando, seu ritmo estimulante, questões retóricas, demandas repetidas que as pessoas escutavam atentamente - seus esforços quase cômicos de clareza demonstram como se envolvia com os ouvintes: "Na medida do possível, viro-me do avesso para vocês." $(\mathrm{Sa}){ }^{86}$
\end{abstract}

"V. Caridade preste atenção. É questão importante, grande questão. ${ }^{87}$ " De todas as formas, o Hiponense procura encontrar meios para que seus ouvintes não fiquem enfadados, desanimados - e é o mesmo que ele deseja transmitir a Deogratias. É preciso ter sensibilidade

\footnotetext{
${ }^{84}$ PAIVA, 2005, p. 23.

${ }^{85}$ De cat. rud., II, 15,23.

86 WILLS, Garry. Santo Agostinho. Rio de Janeiro: Objetiva, 1999. p. 93. (Col. Breves Biografias). A abreviatura "Sa", usada por Wills, refere-se ao grande comentário de Agostinho aos Salmos (Enarrationes in Psalms), composto entre 392 e 417. Trata-se de uma paráfrase, citada sem especificação. Nas palavras do Hiponense: "À medida do possível, fizemos a distinção [entre cítara e saltério], esforçando-nos para que todos entendessem." No contexto, a distinção diz respeito ao som da cítara (físico) e à própria música, que não é um elemento "físico". Por isso: "Ninguém volte o coração para instrumentos musicais usados nos teatros. Ordena-se empregar o que já possuímos dentro de nós, conforme declara outro salmo: 'Em mim, ó Deus, estão os votos de louvor, que cumprirei' (S1 55,12)." (Enn. in Ps., 32, S. I,5).

${ }^{87}$ Enn. in Ps., 35, 10.
} 
para perceber mudanças no ânimo do auditório e, nisso, com algum bom recurso, chamar a atenção dos ouvintes:

Ao percebê-lo, devemos restaurar-lhe o ânimo. Diremos alguma frase temperada com honesta alegria e adequada ao assunto de tratamos. Algo maravilhoso e estupendo... ou aflitivo e lastimável... Algo que diga respeito a ele mesmo para que, picado pelo próprio interesse, desperte. ${ }^{88}$

Na observação de Medeiros: "Essas digressões não são o elemento central do processo de ensino. ${ }^{89 "}$ "Serão inadequadas caso estejam "sendo usadas apenas como arma para remediar o mal do fastio, o qual não deve aumentar pelo uso do próprio remédio. ${ }^{90}$ " Trata-se de um recurso, um paliativo. Assim, e antes de redigir o que seria a sua própria exposição sobre a ação de Deus em favor dos seus escolhidos, o Hiponense diz: "Se algo te agradou em nós e te levou a procurar ouvir de nós alguma observação sobre tua pregação, mais aprenderias vendonos e ouvindo-nos em ação, que lendo o que escrevemos." 90

Pelo modo vivo e pulsante da escrita do Bispo de Hipona, quase podemos mesmo ouvi-lo falar. E, pela procura cada vez maior que se faz à sua "obra pedagógica”, procurando aí os temas relativos à educação, parece que o Hiponense ainda tem muito a nos dizer.

\section{Referências}

AGOSTINHO, Santo. A cidade de Deus: contra os pagãos. 4. ed. Petrópolis: Vozes, 2001. (Col. Pensamento Humano). $2 \mathrm{v}$.

AGOSTINHO, Santo. A doutrina cristã: manual de exegese e formação cristã. São Paulo: Paulos, 2002. (Patrística 17).

AGOSTINHO, Santo. A graça. São Paulo: Paulus, 1998/1999. (Col. Patrística, 12/13). 2 v.

AGOSTINHO, Santo. A instrução dos catecúmenos: teoria e pratica da catequese. 2. ed. Petrópolis: Vozes, 2005.

AGOSTINHO, Santo. Comentário aos Salmos. São Paulo: Paulus, 1997. v. 2. (Col. Patrística, 9/2).

AGOSTINHO, Santo. Confissões. São Paulo: Nova Cultural, 1996. (Col. Os Pensadores).

\footnotetext{
${ }^{88}$ De cat. rud., I, 13,19.

89 MEDEIROS, 2001, p. 185-91.

${ }^{90}$ MEDEIROS, 2001, p. 185-91.

${ }^{90}$ De cat. rud., II, 15,23.
} 
AGOSTINHO, Santo. Contra os acadêmicos: diálogo em três livros. Coimbra: Editorial Atlântida, 1957.

AGOSTINHO, Santo. O mestre. São Paulo: Landy, 2000.

AGOSTINHO, Santo. O sermão da montanha. São Paulo: Paulinas, 1992. (Col. Espiritualidade).

AGOSTINHO, Santo. Solilóquios e A vida feliz. 2. ed. São Paulo: Paulus, 1998. (Col. Patrística, 11).

AGUSTÍN, San. De la verdadera religión. In: Obras completas de San Agustín. Madrid: La Editorial Católica / BAC, 1948. v. 4. Bilíngue.

AGUSTIN, San. Tratados sobre el Evangelio de San Juan (36-124). In: Obras de san Agustín. Madrid: La Editorial Catolica / BAC, 1957. v. 14 (II). Bilíngue.

ALICI, L. Il linguaggio come segno e come testimonianza. Una riletura di S. Agostino. Roma: Studium,1976.

ANGELES NAVARRO GIRON, M. Filosofia del lenguaje en San Agustín. Madrid: Editorial Revista Agustiniana, 2000.

BERNDT, Aldo. Absurdo, revolta e exílio na obra de Albert Camus. In: Estudos teológicos, São Leopoldo, ano 1. n. 1, p. 67-68, 1961.

BOEHNER, Philotheus; GILSON, Etienne. Santo Agostinho, o mestre do Ocidente. In: História da Filosofia Cristã. 2. ed. Petrópolis: Vozes, 1982. p. 139-203.

BURNYEAT, M. F. Wittgenstein and Augustine De magistro. In: MATTHEWS, Gareth B. (Ed.). The augustinian tradition. Berkeley, Los Angeles, London: University of California Press, 1999. p. 286-303.

CAEIRO, Francisco da Gama. Presença de Santo Agostinho no pensamento filosófico português. Didaskalia, Portugal, v. 19, n. 1, p. 81-94, 1989.

CAMUS, Albert Camus. O mito de Sísifo. Lisboa: Livros do Brasil, 2005.

CARTA a Diogneto, A. 2. ed. Petrópolis: Vozes, 1984.

CRICCO, V. Semiótica agustiniana: el diálogo El maestro de San Agustín. Morón: Universidad de Morón, 2000.

DIDAQUÉ: o catecismo dos primeiros cristãos para as comunidades de hoje. 6. ed. São Paulo: Paulus, 1989.

DOMINGUES, Joaquim; GALA, Elísio; GOMES, Pinharanda. Santo Agostinho na cultura portuguesa: contributo bibliográfico. Lisboa: Fundação Lusíada, 2000. (Col. Lusíada Documentos, 3).

FIGUEIREDO, Fernando A. Introdução. In: A CARTA a Diogneto. 2. ed. Petrópolis: Vozes, 1984.

FRANGIOTTI, Roque. Introdução. In: PADRES apologistas: Carta a Diogneto. São Paulo: Paulus, 1995. p. 11-18. (Col. Patrística, 2).

GOMES, J. Pinharanda. Escólio bibliográfico-augustiniano. In: DOMINGUES, Joaquim; GALA, Elísio; GOMES, Pinharanda. Santo Agostinho na cultura portuguesa: contributo bibliográfico. Lisboa: Fundação Lusíada, 2000. p. 83-150. (Col. Lusíada - Documentos, 3). 
GOUVÊA, Ricardo Quadros. Kierkegaard lendo Agostinho: introdução a um diálogo filosófico-teológico. Fides Reformata, São Paulo, v. 4, n. 2, p. 12-37, 1999.

GRENZ, Stanley. Propostas de modelos cristãos. In:

A busca da moral: fundamentos da ética cristã. São Paulo: Vida, 2006. p. 149-92. (Col. Acadêmica).

GRONDIN, Jean. Introduction to Philosophical Hermeneutics. New Haven; London: Yale University Press, 1994.

GUIMARÃES, Almir Ribeiro. Prefácio. In: AGOSTINHO, Santo. A instrução dos catecúmenos: teoria e prática da catequese. 2. ed. Petrópolis: Vozes, 2005. p. 7-8.

HALL, Christopher A. Lendo as escrituras com os pais da Igreja. Viçosa: Ultimato, 2000.

HARE, John E. Augustine, Kant, and the Moral Grap. In: MATTHEWS, Gareth B. (Ed.). The augustinian tradition. Berkeley, Los Angeles, London: University of California Press, 1999. p. 251-62.

HILlGARTH, J. N. Cristianismo e paganismo, 350-750: a conversão da Europa ocidental. São Paulo: Madras, 2004.

HIPÓLITO de Roma. Tradição apostólica. 2. ed. Petrópolis: Vozes, 2004.

HIRSHBERGER, Johannes. História da filosofia na Idade Média. 2. ed. São Paulo: Editora Herder, 1966.

JEAUNEAU, Édouard. A Filosofia Medieval. Lisboa: Edições 70, 1980. (Col. Biblioteca Básica de Filosofia).

JORDÃO, Eduardo Antônio. Agostinho: educação e fé na cidade de Deus. Petrópolis: Vozes, 2009.

KANT, Immanuel. Grundlegung zur Metaphysik der Sitten. Karl Vorländer (Org.). Hamburg: Der philosophischen Bibliotek, 1965. Bd 6 (BA 52).

LE GOFF, Jacques. As raízes medievais da Europa. 2. ed. Petrópolis: Vozes, 2007.

LOQUE, Flávio Fontenelle. A conversa de Pascal com o Sr. de Lacy, ou: Sobre a utilidade da leitura de Epiteto e Montaigne. In: PASCAL, Blaise. Conversa com o Senhor de Sacy sobre Epiteto e Montaigne e outros escritos. São Paulo: Alameda, 2014. p. 7-39.

LOYN, H. R. Artes Liberais. In: Dicionário de Idade Média. Rio de Janeiro: Jorge Zahar Editor, 1997. p. 32.

LUCAS, Miguel. A arte de ensinar: ensine como Santo Agostinho. 3. ed. São Paulo: IBRASA, 1984. (Col. BibliotecaDidática, 32).

LUPI, João. Tomás lê Orígenes. In: DE BONI, Luis A.; PICH, Roberto H. A recepção do pensamento greco-romano, árabe e judaico pelo Ocidente Medieval. Porto Alegre: EDIPUCRS, 2004. p. 487-97. (Col. Filosofia, 171).

MARCONDES, Danilo. Iniciação à História da Filosofia: dos pré-socráticos à Wittgenstein. Rio de Janeiro: Jorge Zahar Ed., 1998.

MARROU, Henri Irénée. A Diognète. Paris: Les Ed. du Cerf, 1955. (Sources Chrétiennes, 33 bis).

MARROU, Henri. Santo Agostinho e o agostinismo. Rio de Janeiro: Livraria Agir Editora, 1957. (Col. Mestres Espirituais). 
MELOT, Michel. Livre,. Paris: L'œil Neuf Éditions, 2006.

MORSE, Richard. O espelho de Próspero: cultura e idéias nas Américas. São Paulo: Companhia das Letras, 1995.

PAIVA, Hugo de V. Introdução. In: AGOSTINHO, Santo. A instrução dos catecúmenos: teoria e pratica da catequese. 2. ed. Petrópolis: Vozes, 2005. p. 9-26.

PASCAL, Blaise. Conversa com o Senhor de Sacy sobre Epiteto e Montaigne e outros escritos. São Paulo: Alameda, 2014.

PEREGRINAÇÃO de Etéria: liturgia e catequese em Jerusalém no século IV. 2. ed. Petrópolis: Vozes, 2004.

PETERS, S. Gabriel. Lire les Pères de l'Église, Cours de patrologie. Paris: Desclé de Brouwer, 1981.

PIAGET, Jean. Où va l'éducation?. Paris: Denoël / Gonthier, 1948.

PRAÇA, Lopes J. J. História da filosofia em Portugal. 3. ed. Lisboa: Guimarães Editores, 1988. (Col. Filosofia e Ensaios).

RAND, Benjamin. (Comp.). The classical moralists. Noston / New York / Chicago: Houghton Mifflin Company / The Riverside Press Cambridge, 1909.

REALE, Giovanni; ANTISERI, Dario. História da filosofia: Antigüidade e Idade Média. 3 ed. São Paulo: Paulus, 1990. (Coleção Filosofia). v. 1.

RIBEIRO, Helcion. Introdução. In: IRINEU DE LIÃO. Contra as heresias: denúncia e refutação da falsa gnose. 2. Ed. São Paulo: Paulus, 1995. p. 9-27. (Col. Patrística, 4).

RINCÓN GONZALEZ, A. Signo y Lenguaje en San Agustín. Bogotá: Universidad Nacionalde Colombia,1992.

RUBIO, Santiago Sierra. Patria y camino: Cristo en la vida y en la reflexión de San Agustín. Madrid: Ediciones Religión y Cultura, 1997.

RUSSEL, Bertrand. História da Filosofia Ocidental. In: Obras filosóficas. 3. ed. São Paulo: Companhia Editora Nacional / CODIL, 1969. 206 p. (Col. Biblioteca do Espírito Moderno: Filosofia). v. 2.

SALES, Antonio Patativa de. A filosofia/teologia moral de Santo Agostinho: dos antecedentes gregos à apropriação e interiorização do elemento cristão e sua recepção no Brasil colonial (15001808). São Leopoldo: EST/PPG, 2009. (Tese de Doutorado).

SANTOS, Bento Silva. Introdução. In: AGOSTINHO, Santo. De magistro. Petrópolis: Vozes, 2009. p. 15-87. (Col. Textos Fundamentais de Educação).

SCHOENBORN, Ulrich. Fé entre História e experiência: migalhas exegéticas. São Leopoldo: Editora Sinodal, 1982.

SECKLER, M. Fé. In: Dicionário de teologia: conceitos fundamentais da teologia atual. 2. ed. São Paulo: Edições Loyola, 1983. p. 192-214. v. 2.

SUOU, J.-P. Le Thème du livre individual des consciences sur les peintures murales du Jugement dernier à la fin du Moyen Âge. In: Enfer et paradis. L'au-delà art et la littérature en Europe. Actes du colloque de Conques, 1993-1994, Les Cahiers de Conques, n. 1, mars 1995, p. 147-75. 
TAYLOR, Charles. As fontes do self: a construção da identidade moderna. São Paulo: Loyola, 1997.

TILLICH, Paul. Introdução. In: Teologia sistemática. 3. ed. São Leopoldo: Sinodal / IEPG, 2000. p. 13-64.

TURCK, André. Evangélisation et catéchèse aux deux premiers siècles. Paris: Ed du Cerf, 1962.

VECCHIO, S. Le parole come segni. Introduzione alla linguistica agostiniana. Palermo: Novecento, 1994.

VOLTAIRE. Ingênuo: história verdadeira, tirada dos manuscritos do Padre Quesnel. In: . Contos. São Paulo: Abril Cultural, 1972. p. 297-359. (Col. Os Imortais da Literatura Universal, 40).

WALKER, Ralph. Kant: Kant e a lei moral. São Paulo: Editora UNESP, 1999. (Col. Grandes Filósofos).

WALKER, Williston. História da Igreja cristã. 4. ed. Rio de Janeiro: JUERP; São Paulo: ASTE, 1983. v. 1.

WILLS, Garry. Santo Agostinho. Rio de Janeiro: Objetiva, 1999. (Col. Breves Biografias).

\section{Textos na Internet}

AGOSTINO, Sant. La vera religione. Disponível em: < http://www.augustinus.it/italiano/vera_religione/index2.htm>. Acesso em 15 de fev. 2011.

GOMES, Rogério. O amor em Santo Agostinho antes de sua Conversão. Disponível em: <http://www.3pinformatica.com.br/redemptor/fotos/fotos/admin/imagens/revistas/pdf/amorhu manoemsantoagostinho.pdf >. Acesso em 03 de fev. 2011.

LAET, Sávio. A educação em Agostinho. Disponível em:

$<$ http://www.filosofante.org/filosofante/not_arquivos/pdf/Educacao_Agostinho.pdf >. Acesso em 17 de jan. 2011.

MEDEIROS, Márcia Medeiros. A instrução pelo riso em Santo Agostinho. Acta Scientiarum. Education, Maringá, v. 32, n. 2, p. 185-191, 2010. Disponível em:

<http://periodicos.uem.br/ojs/index.php/ActaSciEduc/article/viewFile/10429/10429>. Acesso em 13 de fev. 2011.

OLIVEIRA, Terezinha. Agostinho e a Educação Cristã: um olhar da História da Educação. Notandum, Portugal, p. 7, 2008. Disponível em:

<http://www.hottopos.com/notand17/terezinha.pdf>. Acesso em 20 de jan. 2011.

SOUZA, Mariana Rossetto; PEREIRA MELO, José Joaquim. A educação em Santo Agostinho: processo de interiorização na busca pelo conhecimento. III Encontro sul Brasileiro de Psicopedagigia, Paraná, p. 2461. 2009. Disponível em <http://www.pucpr.br/eventos/educere/educere2009/anais/pdf/1937_1302.pdf >. Acesso em 10 de mar. 2011.

\section{Filmes}


SANTO Agostinho. Dir. de Roberto Rossellini. São Paulo: Paulinas / LUCE / Versátil Home Vídeo, 2007. 1 DVD (115 min.), fullscreen, color.

SANTO Agostinho e Santo Tomás de Aquino. São Paulo: ATTA Mídia e Educação / Paulus, 2009. 1 DVD (23:37 min.), color. (Col. Filósofos e Educação). 